\title{
GAMBARAN PERILAKU IBU RUMAH TANGGA TENTANG PENANGGULANGAN DIARE PADA BALITA DI DESA MANGON KECAMATAN SANANA KABUPATEN KEPULAUAN SULA PROVINSI MALUKU UTARA
}

\author{
${ }^{1}$ Agriati Yulin Mus \\ ${ }^{2}$ Grace D. Kandou \\ ${ }^{2}$ Franckie R. R. Maramis \\ ${ }^{1}$ Kandidat Skripsi Fakultas Kedokteran Universitas Sam Ratulangi Manado \\ ${ }^{2}$ Bagian Ilmu Kesehatan Masyarakat Fakultas Kedokteran \\ Universitas Sam Ratulangi Manado \\ Email: mus.yulin@yahoo.com
}

\begin{abstract}
Diarrhea is a disease characterized by changes in the shape and consistency of stools which becomes soft until watery and increase of the frequency of defecation (more than normal three times a day). North Maluku province is one of the islands in Indonesia which is prone to diarrhea. Data of North Maluku Provincial Health Office showed that most children with diarrhea in Mangon village were under five years. This study aimed to find a description of the housewives' behaviour in diarrhea management in children under five years in Mangon village, Sanana Sula Islands, North Maluku Province. This study was a descriptive survey. There were 91 respondents in accordance with the number of cases of diarrhea in children under five. The results showed that the knowledge about diarrhea management were categorized as good in 75 respondents $(82.4 \%)$; the mother's attitude were categorized as good in 48 respondents (52.7\%); and the mothers' actions in diarrhea management were categorized as good enough in 63 respondents (69.2\%). Conclusion: Most mothers of children under five in Mangon village Sanana Sula Islands, North Maluku Province were categorized as good related to their knowledge and attitude in diarrhea management, and were categorized as good enough related to their actions.
\end{abstract}

Keywords: behavior, housewives, handling of diarrhea, children under five

\begin{abstract}
Abstrak: Diare adalah penyakit yang ditandai dengan perubahan bentuk dan konsistensi tinja lembek atau cair dan bertambahnya frekuensi buang air besar lebih dari biasanya (tiga kali dalam sehari). Provinsi Maluku Utara merupakan salah satu wilayah kepulauan di Indonesia yang rawan dengan gejala diare. Data yang diperoleh dari Dinas Kesehatan Propinsi Maluku Utara menunjukkan bahwa kasus diare terbanyak terdapat di Desa Mangon Kecamatan Sanana Kabupaten Sula yang terutama dijumpai pada balita. Tujuan penelitian untuk mengetahui gambaran perilaku ibu rumah tangga tentang penanggulangan diare pada balita di Desa Mangon Kecamatan Sanana Kabupaten Kepulauan Sula Provinsi Maluku Utara. Metode penelitian ini bersifat deskriptif dengan menggunakan metode survei. Jumlah sampel sebanyak 91 responden sesuai dengan jumlah kasus diare pada balita. Hasil penelitian memperihatkan bahwa pengetahuan ibu tentang penanggulangan diare pada anak balita di desa Mangon termasuk kategori baik sebanyak 75 responden $(82,4 \%)$, sikap ibu balita yang termasuk kategori baik sebanyak 48 responden $(52,7 \%)$, dan tindakan ibu balita termasuk kategori cukup sebanyak 63 responden (69,2 \%). Simpulan: Sebagian besar pengetahuan dan sikap ibu balita terhadap penanggulangan diare di desa Mangon Kecamatan Sanana Kabupaten Sula Propinsi Maluku Utara termasuk kategori baik sedangkan tindakan penanggulangan diare termasuk kategori cukup.
\end{abstract}

Kata Kunci: perilaku, ibu rumah tangga, penaggulangan diare, balita. 
Diare merupakan salah satu penyebab utama kematian balita, dengan angka insiden mencapai 60-80 persen, dan kematian sebesar tiga persen menyerang terutama pada dua tahun pertama usia anak. Penyakit diare adalah penyakit yang ditandai dengan perubahan bentuk dan konsistensi tinja lembek sampai cair serta bertambahnya frekuensi berak lebih dari biasanya (tiga kali dalam sehari). Secara operasional diare balita dapat dibagi dua klasifikasi, yaitu: diare akut dan diare bermasalah. Diare akut adalah diare yang ditandai dengan buang air besar lembek/cair bahkan dapat berupa air saja yang frekuensinya lebih sering dari biasanya (tiga kali atau lebih dalam sehari) dan berlangsung kurang dari 14 hari. Adapun diare bermasalah terdiri dari disentri berat, diare persisten, diare dengan kurang energi protein (KEP) berat, dan diare dengan penyakit penyerta. ${ }^{1}$

Faktor resiko yang sangat berpengaruh untuk terjadinya diare yaitu status kesehatan lingkungan dan perilaku hidup sehat dalam keluarga, sedangkan secara klinis dapat disebabkan oleh infeksi, malabsorpsi, alergi, keracunan,imunisasi,dan defisiensi. ${ }^{2}$

Provinsi Maluku Utara merupakan salah satu wilayah kepulauan di Indonesia yang rawan dari gejala penyakit diare. Data yang diperoleh pada Dinas Kesehatan Propinsi Maluku Utara pada tahun 2009 menyebutkan angka penyakit diare pada balita mencapai $45,15 \%$, dengan $15,45 \%$ pada kelompok usia kurang dari tahun dan 29,70\% pada kelompok usia satu sampai empat tahun.

Penelitian ini bertujuan untuk mengetahui gambaran perilaku ibu rumah tangga tentang penanggulangan diare pada anak balita di desa Mangon Kecamatan Sanana Kabupaten Kepulauan Sula Provinsi Maluku Utara.

\section{METODE}

Penelitian ini bersifat deskriptif dengan menggunakan metode survei dan desain cross sectional. Penelitian dilak- sanakan di Desa Mangon Kecamatan Sanana Kabupaten Kepulauan Sula Provinsi Maluku Utara di Desa Mangon Kecamatan Sanana Kabupaten Kepulauan Sula. Jumlah balita di 25 Desa Mangon sebanyak 442 balita dan jumlah kasus diare pada balita sebanyak 91 penderita.

Perilaku ibu rumah tangga merupakan variabel independen atau variabel bebas sedangkan penanggulangan diare pada balita adalah variabel dependen atau variable terikat. Data yang dikumpulkan dan diolah data primer dan data sekunder.

Data primer berupa identitas responden, karakteristik responden, dan perilaku responden yang diperoleh melalui wawancara langsung kepada responden dengan menggunakan kuesioner, sedangkan data sekunder berupa gambaran umum tentang Desa Mangon Kecamatan Sanana Kabupaten Kepulauan Sula Provinsi Maluku Utara.

Untuk Pengetahuan didasarkan pada kategori sangat baik, baik, cukup baik, dan kurang baik maka didapatkan skala interval $($ skor tertinggi - skor terendah $)=(20-0)=$ 544 , sehingga untuk setiap kategori diberi interval 5 .

Untuk Sikap didasarkan pada kategori sangat baik, baik, cukup baik, dan kurang baik maka didapatkan skala interval (Skor tertinggi - skor terendah $)=(50-10)=10$

44 , sehingga untuk setiap kategori diberi interval 10 .

Untuk Tindakan didasarkan pada kategori sangat baik, baik, cukup baik, dan kurang baik maka didapatkan skala interval $($ Skor tertinggi - skor terendah $)=(20-0)=$ 544 , sehingga untuk setiap kategori diberi interval 5.

\section{HASIL DAN BAHASAN}

Tingkat pendidikan masyarakat yang ada di Desa Mangon sebagian besar adalah tamatan SMP dan SMA. Potensi yang ada ini dapat ditambah dengan pembekalan keterampilan maupun peningkatan sumber daya manusia. Pendidikan yang diperoleh masyarakat setempat diperlukan agar lewat pendidikan dapat meningkatkan taraf hidup sehingga terhindar dari kebodohan dan 
kemiskinan.

Hasil penelitian yang telah dilakukan pada 91 orang responden yang merupakan ibu dari balita menunjukkan bahwa pada umumnya responden berada pada kelompok usia $20-25$ tahun $(36,3 \%)$.

Berdasarkan pekerjaan paling banyak sebagai IRT $(51,6 \%)$. Ibu merupakan orang terdekat dengan balita sehingga diharapkan semakin banyak waktu yang ibu luangkan buat anak maka akan semakin baik perawatan ibu dalam masa perkembangan dan pertumbuhan balita.

Aspek dalam perilaku terdiri dari pengetahuan, sikap dan tindakan. Pengetahuan merupakan kemampuan untuk membentuk model mental yang menggambarkan objek dengan tepat dan mempresentasikannya dalam aksi yang dilakukan terhadap suatu obyek. $^{3}$

Hasil penelitian menunjukkan bahwa terbanyak responden memiliki pengetahuan yang baik tentang penanggulangan diare pada balita yaitu sebanyak 75 orang $(82,4 \%)$; terbanyak responden memiliki sikap yang baik tentang penanggulangan diare pada balita yaitu sebanyak 48 orang $(52,7 \%)$; dan terbanyak responden memiliki tindakan yang cukup baik tentang penanggulangan diare pada balita yaitu sebanyak 63 orang atau $69,2 \%$.

Hasil penelitian ini di dukung oleh penelitian yang dilakukan oleh Ginting (2011) yang mengemukakan adanya hubungan yang bermakna antara kejadian diare pada balita dengan sikap dan pengetahuan ibu tentang kebiasaan hidup bersih dan sehat melalui uji Chi Square. Pengetahuan dan sikap ibu terhadap kebiasaan hidup bersih dan sehat berpengaruh terhadap status kesehatan anak dalam kesehariannya. ${ }^{4}$

Pengetahuan dan kesadaran orang tua terhadap kesehatan anaknya itu sangat penting agar anak yang sedang mengalami diare tidak jatuh pada kondisi yang lebih buruk tentunya hal ini duwujudkan dalam bentuk suatu tindakan. Orang tua wajib mengetahui langkah apa saja yang harus dilakukan jika anaknya mengalami diare. Pada tahap awal berikan cairan secara oral dan teruskan pemberian makanan selama anak mau. Jika diare berlanjut dengan frekuensi yang cukup sering (lebih dari enam kali) disertai muntah yang frekuen, atau frekuensi tidak terlalu sering tetapi feces disertai lendir atau darah, sebaiknya anak dibawa ke pusat layanan kesehatan untuk mendapatkan terapi lebih lanjut. Pada kasus dehidrasi sedang dan berat penderita diare memerlukan rehidrasi intravena (infus) untuk menggantikan cairan yang hilang. ${ }^{5}$

\section{SIMPULAN}

Pengetahuan ibu tentang penanggulangan diare pada anak balita di desa Mangon Kecamatan Sanana Kabupaten Kepulauan Sula Provinsi Maluku Utara berada dalam kategori baik.

Sikap ibu tentang penanggulangan diare pada anak balita di desa Mangon Kecamatan Sanana Kabupaten Kepulauan Sula Provinsi Maluku Utara berada dalam kategori baik.

Tindakan ibu tentang penanggulangan diare pada anak balita di desa Mangon Kecamatan Sanana Kabupaten Kepulauan Sula Provinsi Maluku Utara berada dalam kategori cukup.

\section{SARAN}

Bagi tenaga kesehatan diharapkan dapat memberikan informasi melalui promosi kesehatan didukung oleh adanya pela-tihan penanganan diare pada masyarakat untuk meningkatan perilaku yang benar pada penanganan diare.

Bagi masyarakat diharapkan dapat membuka diri dalam menerima informasi yang di berikan dengan didukung oleh suatu sikap yang meng-arah pada perilaku hidup bersih dan sehat

\section{DAFTAR PUSTAKA}

1. Kolopaking MS. Penatalaksanaan muntah dan diare akut [homepage on the Internet]. Nodate [cited ???]. Available from: http://www.infodokterku.com/index.php?o ption $=$ com_content\&view $=$ article $\&$ id $=81: p$ enanganan-diare-pada-bayi-dan-anak-bali ta-di-tingkat-rumah-tangga\&catid=25:pe 
20 Jurnal e-Biomedik (eBM), Volume 1, Nomor 1, Maret 201, hlm. 17-20

nyakit-menular\&Itemid $=18$

2. Dep Kes RI. Buku Ajar Diare. Jakarta: penerbit, 1999; hal.1-22.

3. Kusrini. Sistem Pakar Teori dan Aplikasi. (Edisi Pertama). Yogyakarta: penerbit, 2006.

4. Ginting SBR. Hubungan antara kejadian diare pada balita dengan sikap dan pengetahuan ibu tentang PHBS di puskesmas Siantan Hulu Pontianak
Kalimantan Barat [homepage on the Internet]. 2011 [cited 2012 Jan 20]. Available from: http:// www.fk.unair.ac.id/ attachments/1589 Srimurni\%20Br\%20Gint ing.pdf. Diakses 20 Januari 2012.

5. Kuntari T. Rehidrasi, tindakan penting atasi diare [homepage on the Internet]. 2009 [cited 2012 Jan 12]. Available from: http://medicine.uii.ac.id/index.php/Artikel/r ehidrasi-tindakanpenting-atasi-diare.html. 